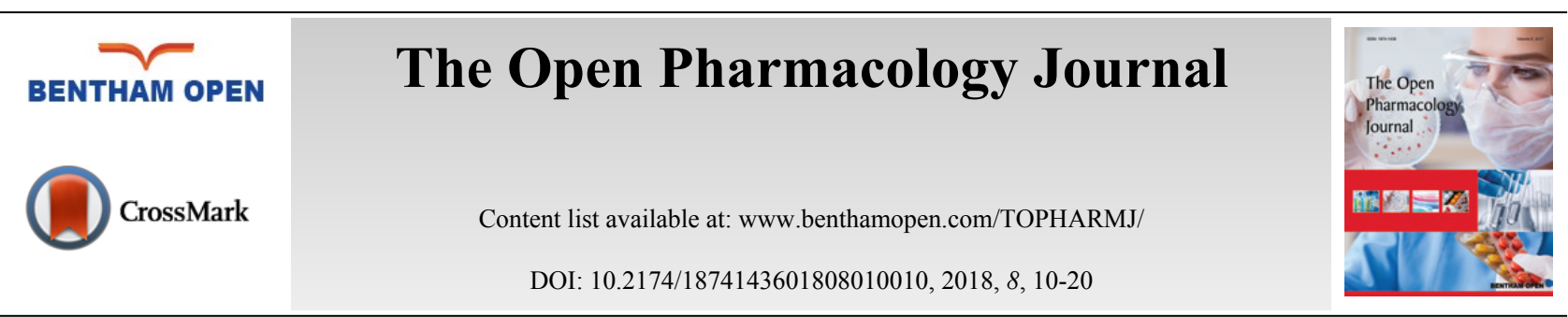

RESEARCH ARTICLE

\title{
New Amino-steroid-anthracenone with Biological Activity Against Ischemia-reperfusion Injury in a Wistar Rat Model
}

Figueroa-Valverde Lauro ${ }^{1, *}$, Rosas-Nexticapa Marcela, ${ }^{2, *}$, Mateu-Armand Virginia ${ }^{2}$, Herrera-Meza Socorro $^{3}$, Díaz-Cedillo Francisco ${ }^{4}$, Montano-Tapia Elizabeth ${ }^{2}$, García-Cervera Elodia ${ }^{1}$, Pool-Gómez Eduardo ${ }^{1}$, Hau-Heredia Lenin ${ }^{1}$, García-Martínez Rolando ${ }^{1}$, Lopez-Ramos Maria ${ }^{1}$, Cauich-Carrillo Regina $^{1}$ and Parra-Galindo Perla ${ }^{2}$

${ }^{1}$ Laboratory of Pharmaco-Chemistry, Faculty of Chemical Biological Sciences, University Autonomous of Campeche, Av. Agustín Melgar s/n, Col Buenavista, C.P. 24039, Campeche, México

${ }^{2}$ Facultad de Nutrición, Universidad Veracruzana, Médicos y Odontologos s/n C.P. 91010, Unidad del Bosque, Xalapa, Veracruz, México

${ }^{3}$ Instituto de Investigaciones Psicológicas, Universidad Veracruzana, Av. Dr. Luis Castelazo Ayala s/n Col Industrial Animas, C.P. 91190, Xalapa, Veracruz, México

${ }^{4}$ Escuela Nacional de Ciencias Biológicas del Instituto, Politécnico Nacional. Prol. Carpio y Plan de Ayala s/n Col. Santo Tomas, D.F. C.P. 11340, México

\section{Abstract:}

\section{Objective:}

The main objective of this study was to evaluate the biological activity of an ASA (Amino-Steroid-Anthracenone derivative) against heart failure caused by the ischemia- reperfusion injury (translated as infarct area).

\section{Methods:}

Biological activity exerted by ASA (0.001-100 nM) on infarct area was determined using an ischemia-reperfusion injury model. In addition, to characterize the molecular mechanism involved in the effect exerted by ASA on left ventricular pressure, some drugs such as estrone (0.001-100 $\mathrm{nM})$, tamoxifen $(1 \mathrm{nM})$, butoxamine $(1 \mathrm{nM})$ and ZM-241385 $(1 \mathrm{nM})$ were used.

Results:

The experimental data showed that ASA decreased the infarction area significantly $(p=0.05)$ compared to estrone. Other results indicated that ASA decreased left ventricular pressure and this effect was inhibited by ZM-241385. In addition, ASA increased cAMP levels in a time-dependent manner compared to control conditions.

\section{Conclusion:}

The results showed that ASA decreases ischemia-reperfusion injury (translated as infarct area) via $\mathrm{A}_{2}$ adenosine receptor activation and these phenomena involve changes in cAMP levels.

Keywords: Amino-steroid-anthracenone, Ischemia, Reperfusion, cAMP, Adenosine, ZM-241385.

\footnotetext{
* Address correspondence to these authors at the Laboratory of Pharmaco-Chemistry, Faculty of Chemical Biological Sciences, University Autonomous of Campeche, Av. Agustín Melgar s/n, Col Buenavista, C.P. 24039, Campeche, México; Facultad de Nutrición, Universidad Veracruzana, Médicos y Odontologos s/n C.P. 91010, Unidad del Bosque, Xalapa, Veracruz, México; Tel: 9818119800; E-mails: lauro_1999@yahoo.com, rosasnm@yahoo.com.mx
} 


\section{INTRODUCTION}

There are some reports which indicate that congestive heart failure has increased in recent years worldwide [1, 2]. It is important to mention that congestive heart failure (translated as myocardial infarction) can induce cardiomyocyte cell death and result in a decrease of cardiac work [3 - 5]. Some drugs are used for the treatment of this clinical pathology, such as angiotensin-converting-enzyme inhibitors [6], $\beta_{1}$-adrenergic agonist or $\beta_{1}$-adrenergic blockers [7], diuretics [8], angiotensin-receptor inhibitors [9], calcium sensitizer [10], phosphodiesterase III inhibitors [11], ATP-ase inhibitors [12] and others. However, some of these drugs can produce adverse effects [13 - 18]; therefore, in the search for a new drug for the treatment of heart failure and ischemia-reperfusion injury, several drugs have been developed such as MK-7145 (potassium channel inhibitor) [19], some heteroaryl-substituted naphthalenes (CYP11B2 inhibitors) [20, 21], BAY-1021189 (guanylate cyclase stimulator) [22], $N$-benzylcarboxamide (G-protein-coupled receptor kinase 2 inhibitor) [23], a naphthalene-prazosin derivative (calcium channels activation) [24], a guanidine analog (sodiumhydrogen exchanger isoform inhibitor) and others. All these data indicate that several drugs may exert effects on heart failure and ischemia-reperfusion injury; however, the molecular mechanism is very confusing, perhaps, this phenomenon can be due to; 1) differences in the chemical structure of each drug; or 2) to different protocols used in each experiment. Therefore, in this study, the biological activity of an Amino-Steroid-Anthracenone (ASA) (Fig. 1) was evaluated using an ischemia-reperfusion injury model.

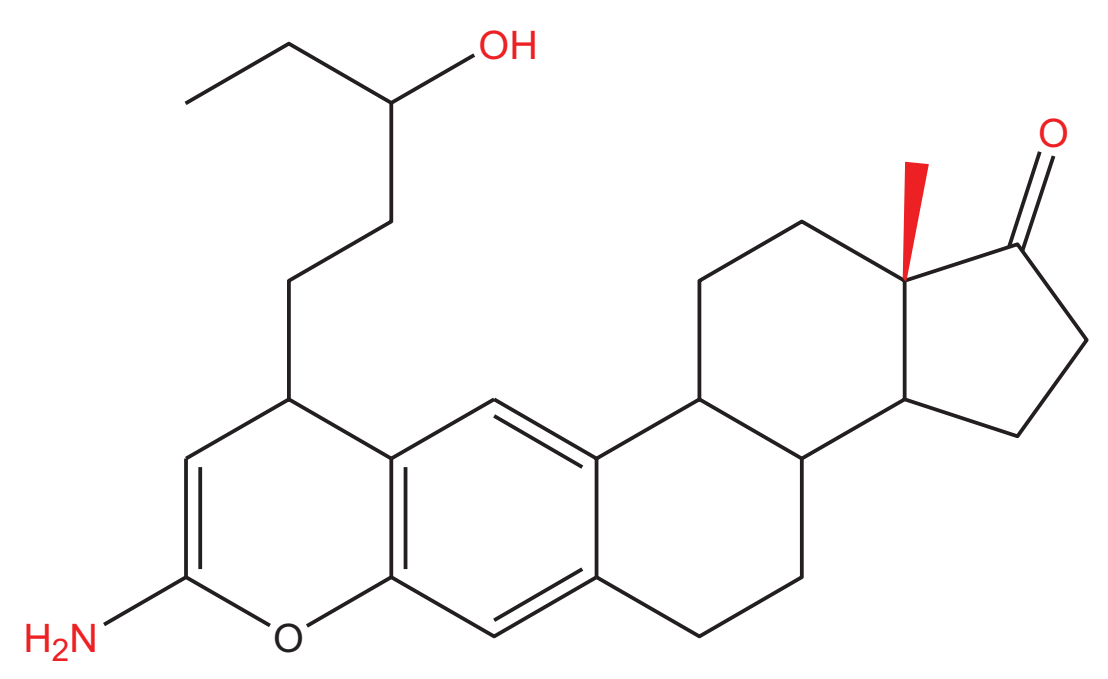

Fig. (1). Chemical structure of ASA (8-Amino-10-(3-hydroxy-pentyl)-13a-methyl-3,3a,3b,4,5,10,11b,12,13,13a-decahydro-2H-7oxa-indeno[5,4-a]anthracen-1-one).

\section{MATERIALS AND METHODS}

\subsection{General Methods}

The compound amino-steroid-anthracenone derivative (ASA; 8-Amino-10-(3-hydroxy-pentyl) -13a-methyl-3, 3a, $3 \mathrm{~b}, 4,5,10,11 \mathrm{~b}, 12,13,13 \mathrm{a}$-decahydro-2H-7-oxa-indeno [5,4-a]anthracen-1-one) was prepared using a previously reported method [25].

All experimental procedures and protocols used in this investigation were reviewed and approved by the Animal care and use committee of Autonomous University of Campeche (Faculty of Chemical-Biological Sciences) with No. PI-420/12 and were in accordance with the Guide for the Care and Use of Laboratory Animals [26]. Male Wistar rats; weighing 200-250 g were obtained from Pharmacochemistry Laboratory of University Autonomous of Campeche (Faculty of Chemical-Biological Sciences).

\subsection{Reagents}

It is noteworthy that the drugs involved in this study were dissolved in methanol and from this solution, all dilutions were done using a Krebs-Henseleit* solution (v/v). 


\subsection{Biological Activity}

\subsubsection{Experimental Design I}

Animals were anesthetized with pentobarbital ( $50 \mathrm{mg} / \mathrm{Kg}$ body weight) via intraperitoneal administration. After the animal was opened by a thoracic abdominal laparotomy, the heart was perfused via retrograde with the Krebs-Henseleit solution through a non-circulating perfusion system with a constant flow rate. It is important that the study population involved in each group was $\mathrm{n}=9$. *Krebs-Henseleit system was composed of the following substances in mmol concentrations per liter; $117.8 \mathrm{NaCl} ; 6 \mathrm{KCl} ; 1.75 \mathrm{CaCl}_{2} ; 1.2 \mathrm{NaH}_{2} \mathrm{PO}_{4} ; 1.2 \mathrm{MgSO}_{4} ; 24.2 \mathrm{NaHCO}_{3} ; 5$ glucose, and 5 sodium pyruvate [27]. The solution was then bubbled with a mixture of $\mathrm{O}_{2} / \mathrm{CO}_{2}(95: 5 / 5 \%)$ and the mixture was regulated to a $\mathrm{pH}$ of $7.4\left(37^{\circ} \mathrm{C}\right)$. The coronary flow $(10 \mathrm{~mL} / \mathrm{min})$ was adjusted with a peristaltic pump for an equilibration period of $15 \mathrm{~min}$.

\subsubsection{Ischemia-reperfusion Model}

It is important to mention that after the equilibrium time, the hearts underwent a period of ischemia for a duration of 40 mins due to the closure of the perfusion system as indicated in some reports [24], in the absence (control) or in the presence of each of the drugs involved in this study. Following this, the system was restarted, and the hearts were reperfused for another 40 mins with Krebs-Henseleit solution.

\subsection{Biological Evaluation}

\subsubsection{Step I}

\subsubsection{Effects Induced by the Compound}

Amino-Steroid-Anthracenone derivative (ASA) against infarct area. The effect induced by ASA on ischemiareperfusion injury (translated as infarction area*) was evaluated at a dose range of 0.001-100 nM.

\subsubsection{Biological Activity Produced by Estrone and ASA Against Infarct Area}

The effect induced by estrone (has a steroid nucleus similar to ASA) at a dose range of 0.001-100 $\mathrm{nM}$ on the ischemia-reperfusion injury (translated as infarction area*) was determined.

*The infarction area was determined through a previously reported planimetry method [28] using an image-Pro Plus 4.5 software (Media cybernetics, Silver Spring, USA).

\subsubsection{Step II}

\subsubsection{Effects Induced by ASA on Left Ventricular Pressure Through Estrogen Receptor Activation}

Intracoronary boluses $(50 \mu \mathrm{L})$ of the ASA $(0.001$ to $100 \mathrm{nM})$ were administered and the corresponding effect on the left ventricular pressure was determined. The dose-response curve (control) was repeated in the presence of tamoxifen (estrogen inhibitor) at a concentration of $1 \mathrm{nM}$ (duration of pre-incubation with tamoxifen was 10 min equilibration period).

\subsubsection{Effects Induced by the ASA on Left Ventricular Pressure Through B,-Adrenergic Receptor Stimulation}

Intracoronary boluses $(50 \mu \mathrm{L})$ of ASA $(0.001$ to $100 \mathrm{nM})$ were administered and the corresponding effect on the left ventricular pressure was determined. The dose-response curve (control) was repeated in the presence of butoxamine $\left(\beta_{2}-\right.$ selective beta blocker) at a concentration of $1 \mathrm{nM}$ (duration of pre-incubation with butoxamine was 10 min equilibration period).

\subsubsection{Effect Exerted by ASA on Left Ventricular Pressure Through $A_{2}$-Purinergic Receptor Activation}

The boluses $(50 \mu \mathrm{L})$ of ASA $(0.001$ to $100 \mathrm{nM})$ were administered and the corresponding effect on the left ventricular pressure was evaluated. The bolus injection administered was done at the point of cannulation. The doseresponse curve (control) was repeated in the presence of ZM-241,385 (adenosine $\mathrm{A}_{2}$ antagonist) at a concentration of 1 $\mathrm{nM}$ (duration of the pre-incubation with ZM-241,385 was for a period of $10 \mathrm{~min}$ ). 


\subsubsection{Effect Exerted of ASA on cAMP Concentration}

Isoproterenol ( $\beta_{2}$ adrenoreceptor agonist) was perfused at a dose of $100 \mathrm{nM} / \mathrm{min}$ on the heart for 3, 6, 9, 12 or 18 minutes and its effect on cAMP levels was determined using a previously reported method [24]. The results obtained were compared with the biological activity exerted by ASA $(1 \mathrm{nM} / \mathrm{min})$ on the concentration of cAMP as against the controls.

\subsection{Statistical Analysis}

The results were expressed as average \pm SE, using each heart $(n=9)$ as its own control. In addition, the results were analyzed via Analysis of Variance using the SPSS 12.0 program The differences in the values found were determinates of $p \leq 0.05$ [29].

\section{RESULTS}

In this study, the biological activity induced by an Amino-Steroid-Anthracenone derivative (ASA) with biological activity against ischemia-reperfusion injury was evaluated.

\subsection{First Stage}

\subsubsection{Effect Exerted of ASA on Ischemia/Reperfusion Injury}

The results (Fig. 2) showed that the ASA reduces infarct size significantly $(\mathrm{p}=0.05)$ expressed as a percentage of the area at a risk compared with vehicle-treated hearts (control).

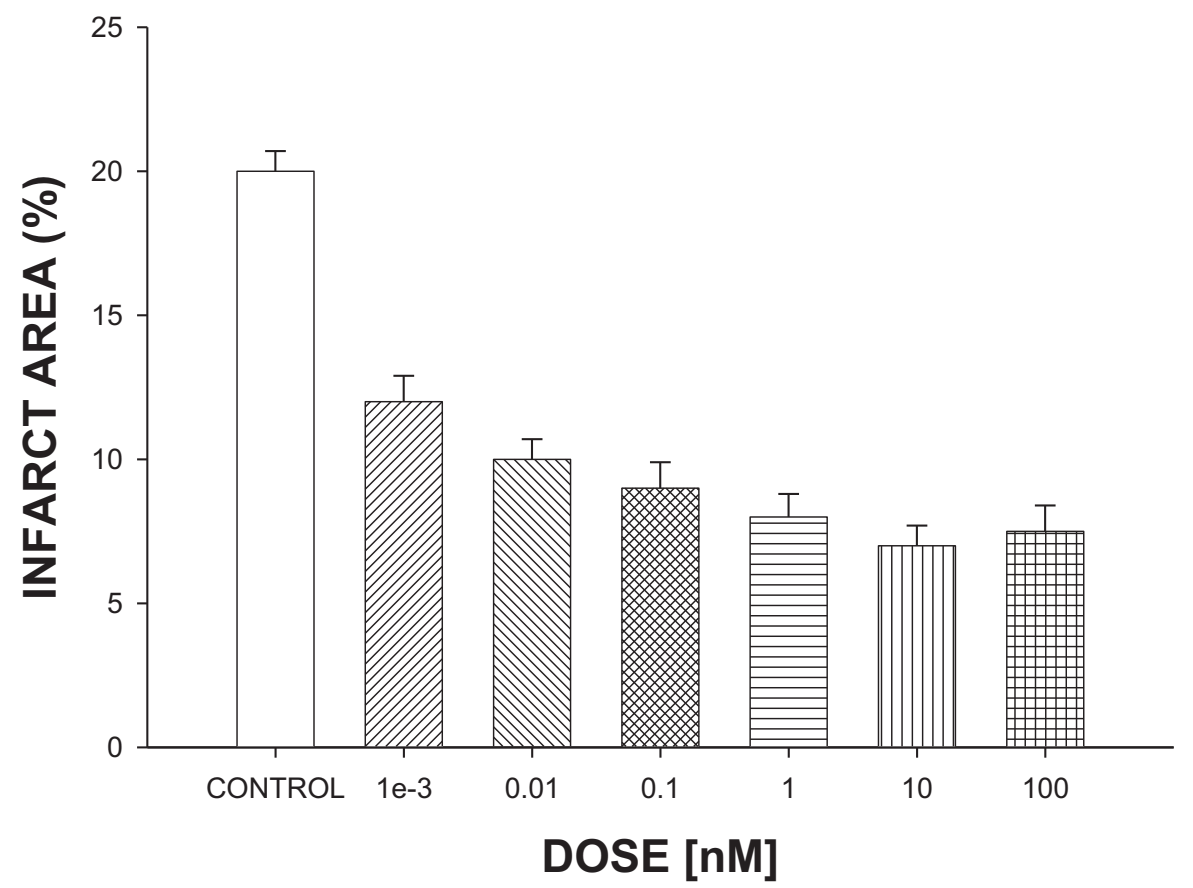

Fig. (2). Biological activity exerted by an amino-steroid-anthracenone derivative (ASA; 0.001-100 nM) against ischemia-reperfusion injury (translated as infarct area). The experimental data showed that ASA decreased infarct size (expressed as a percentage of the area at risk) in a dose-dependent manner compared with the vehicle-treated hearts (control). Each bar represents the mean \pm S.E. of 9 experiments.

\subsubsection{Biological Activity Induced by Both Estrone and ASA on Ischemia/Reperfusion Injury}

The experimental data (Fig. 3) showed that the infarct area was significantly reduced $(p=0.05)$ in the presence of ASA compared with estrone in a dose-dependent manner ( 0.001 to $100 \mathrm{nM})$. 


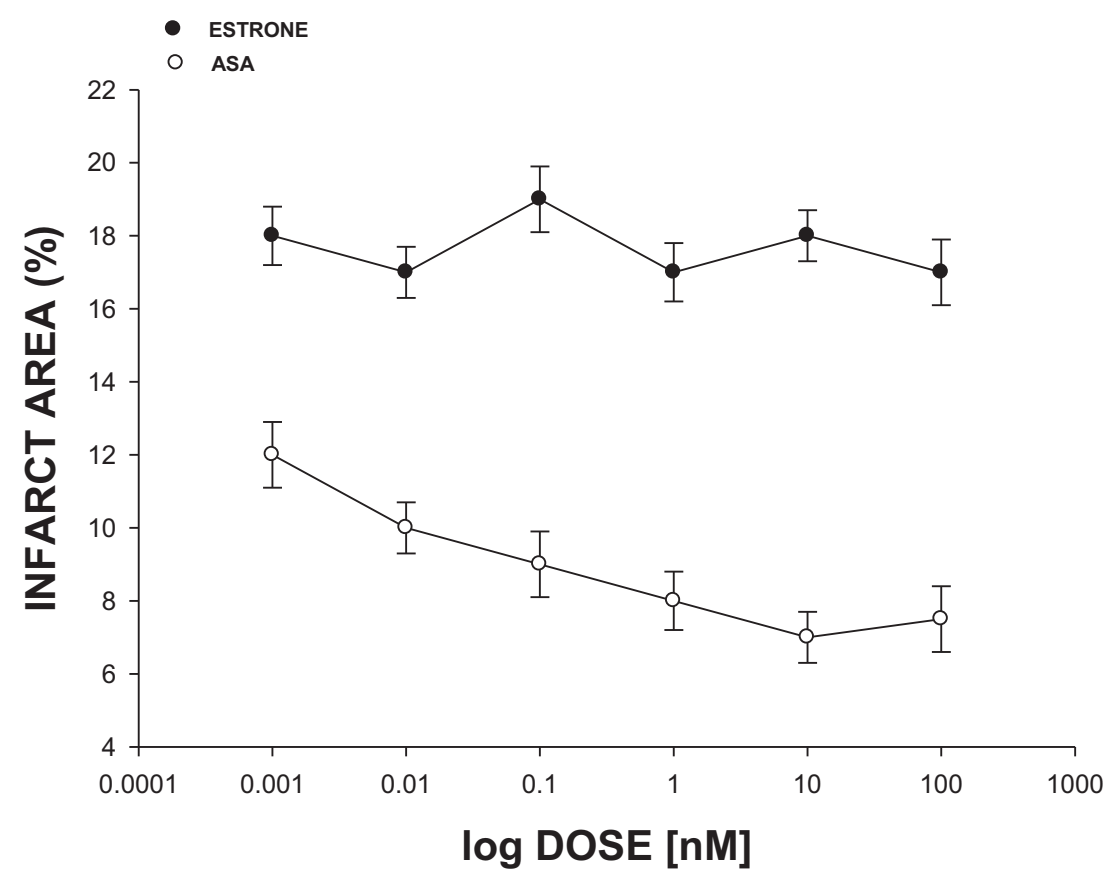

Fig. (3). Effect exerted by both estrone and an amino-steroid-anthracenone derivative (ASA; 0.001-100 nM) against ischemiareperfusion injury (translated as infarct area). The results showed that ASA significantly $(p=0.05)$ reduced infarct size expressed as a percentage of the area at risk compared with the estrone. Each data points represents the mean \pm S.E. of 9 experiments.

\subsection{Second Stage}

\subsubsection{Effects Induced by ASA on Left Ventricular Pressure Through Estrogen Receptor Activation}

Fig. 4 shows that ASA ( 0.001 to $100 \mathrm{nM})$ decreased the left ventricular pressure in a dose-dependent manner, both in the absence or the presence of tamoxifen $(1 \mathrm{nM})$.

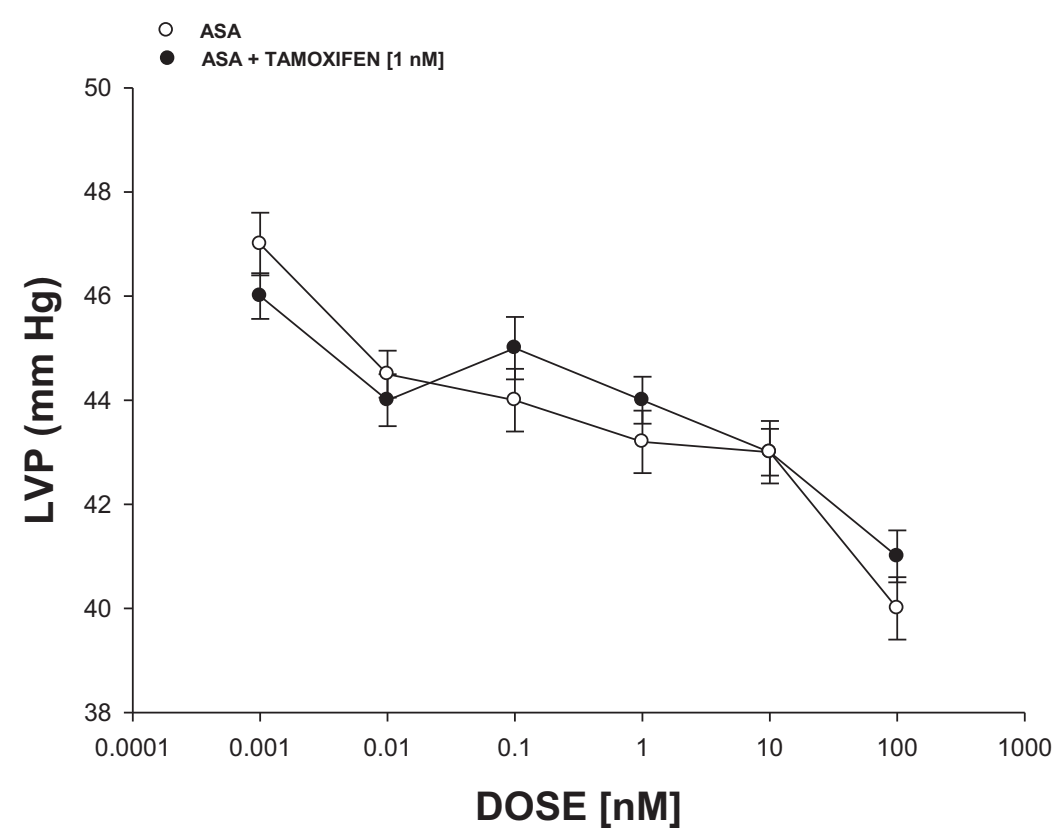

Fig. (4). Biological activity induced by an Amino-Steroid-Anthracenone derivative (ASA; 0.001-100 nM) on Left Ventricular Pressure (LVP) in absence or presence of tamoxifen. The experimental results showed that ASA significantly decreased LVP $(p=$ $0.05)$ in a dose-dependent manner and this effect was not inhibited in presence of tamoxifen. Each data points represents the mean \pm S.E. of 9 experiments. 


\subsubsection{Effects Induced by the ASA on Left Ventricular Pressure Through $B_{2}$-Adrenergic Receptor Stimulation}

The experimental data (Fig. 5) indicated that PDC (0.001 to $100 \mathrm{nM})$ decreased the left ventricular pressure in a dose-dependent manner in the absence or the presence of butoxamine [1 nM].

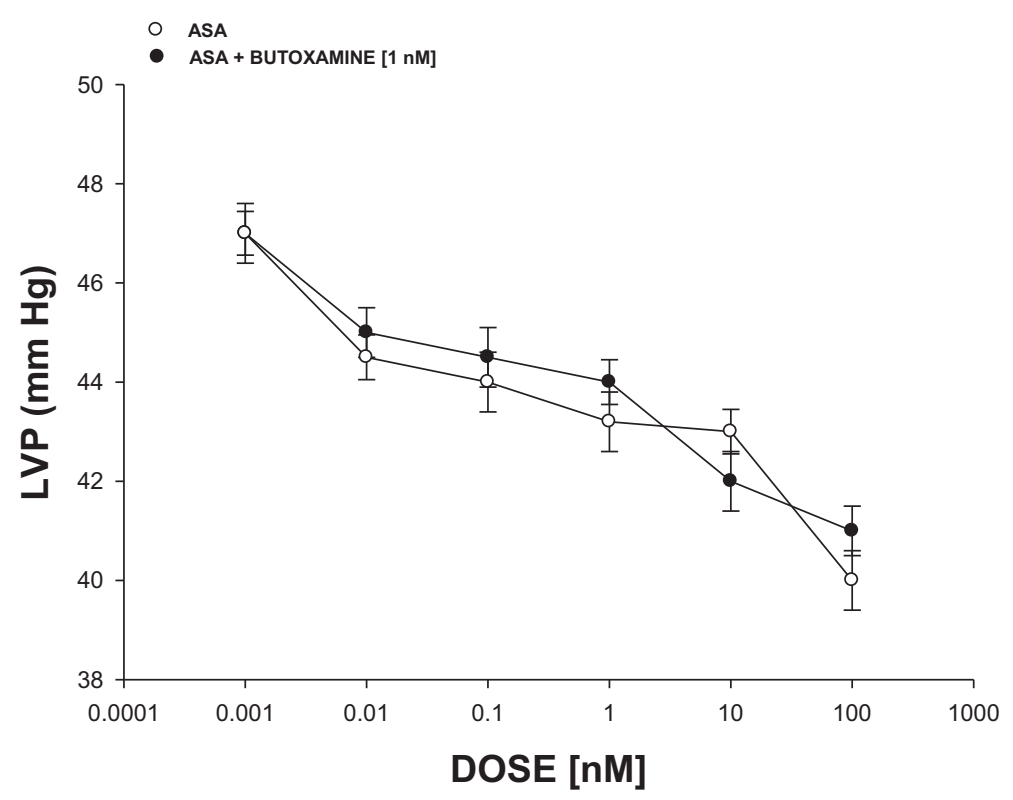

Fig. (5). Effect exerted by an Amino-Steroid-Anthracenone (ASA; 0.001-100 nM) on Left Ventricular Pressure (LVP) in absence or presence of butoxamine. The results showed that ASA significantly decreased LVP $(p=0.05)$ in a dose-dependent manner and this effect was not inhibited in presence of butoxamine. Each data points represents the mean \pm S.E. of 9 experiments.

\subsubsection{Effect Exerted by ASA on Left Ventricular Pressure Through $A_{2}$-Purinergic Receptor Activation}

The results shown in Fig. 6 showed that ASA $(0.001$ to $100 \mathrm{nM})$ decreased the left ventricular pressure in a dosedependent manner and this effect was inhibited in the presence of ZM-241,385 [1 nM].

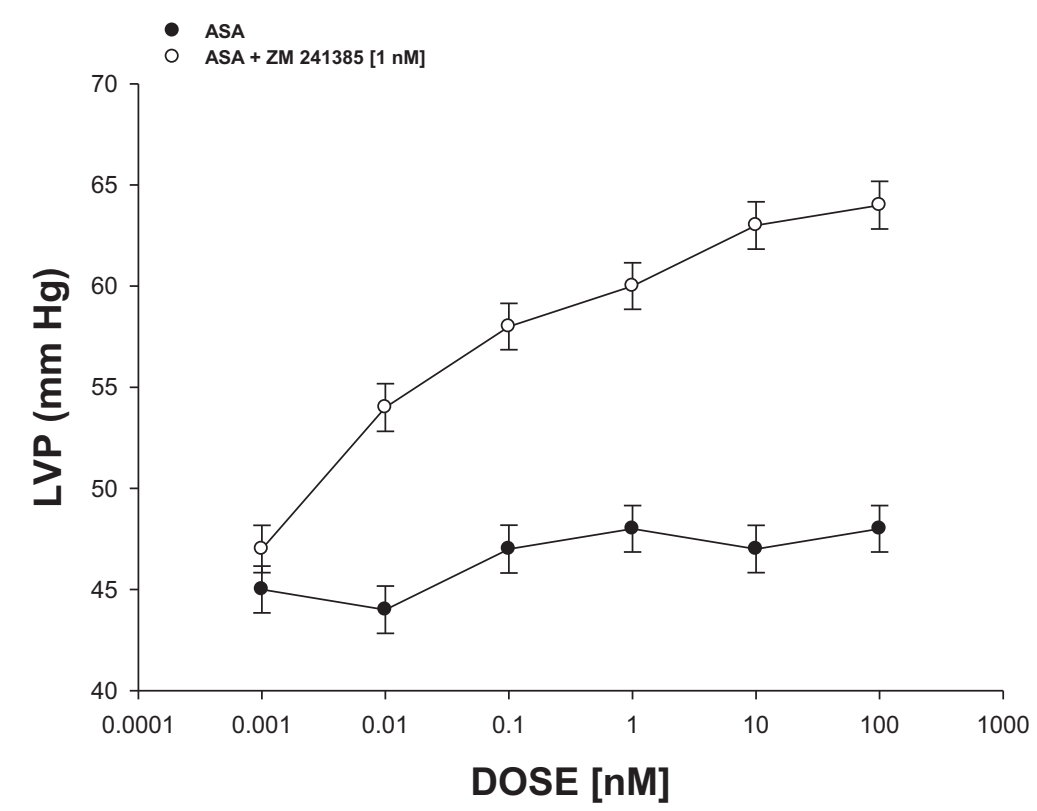

Fig. (6). Biological activity exerted by an Amino-Steroid-Anthracenone derivative (ASA) on Left Ventricular Pressure (LVP) in absence or presence of the compound ZM241385. The experimental results showed that ASA significantly decreased LVP $(p=0.05)$ in a dose-dependent manner and this effect was inhibited by ZM241385. Each data points represents the mean \pm S.E. of 9 
experiments.

\subsubsection{Effect Exerted of ASA on cAMP Concentration} $\min )$.

The results (Fig. 7) showed that ASA (1 nM/min) increased the cAMP levels in a time-dependent manner (3-18

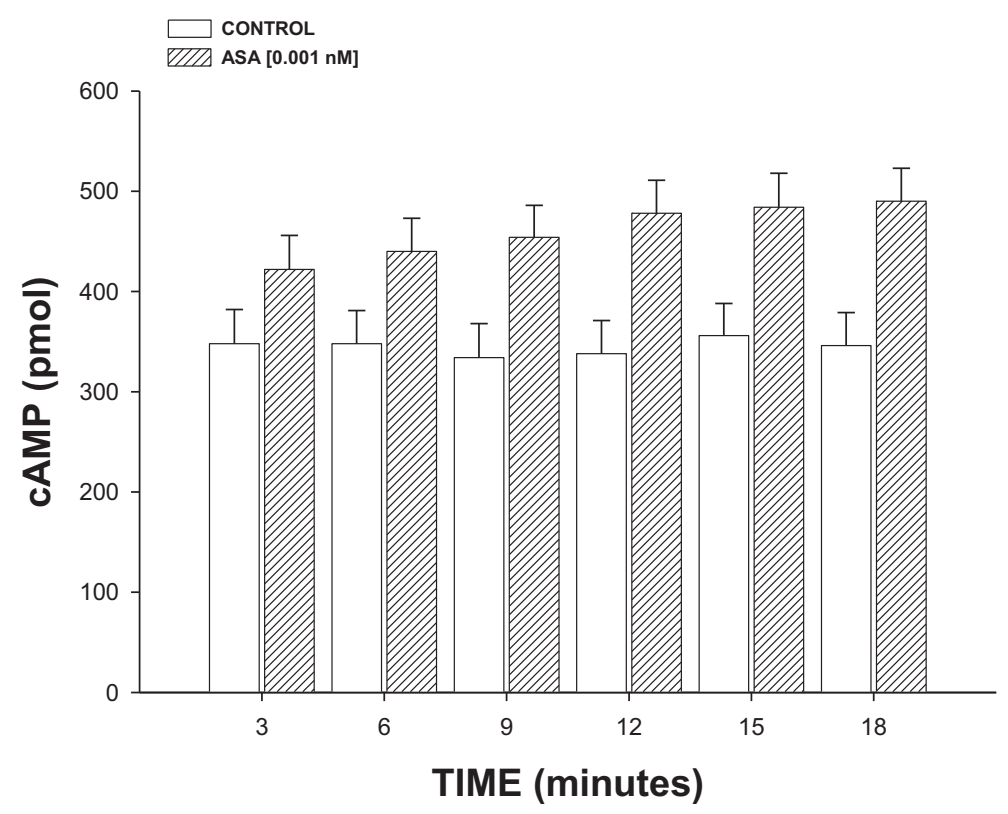

Fig. (7). Effect exerted by an Amino-Steroid-Anthracenone derivative (ASA) on cAMP levels in a time dependent manner (3 - 18 min). The experimental data showed that ASA increases cAMP levels $(\mathrm{p}=0.05)$ with increase in time $(3-18$ min $)$ compared to the control. Each bar represents the mean \pm S.E. of 9 experiments.

\section{DISCUSSION}

There are several drugs that have been used to treat heart failure resulting from myocardial ischemia [30, 31]. Nevertheless, there is scarce information about the effects of the Amino-Steroid-Anthracenone (ASA) on this clinic pathology. Therefore, in this study, the biological activity of an ASA against myocardial ischemia translated as infarct area was evaluated using an ischemia-reperfusion injury model [32]. The results showed that ASA reduces infarct size (expressed as a percentage of the area at risk) to different doses compared with conditions control. In order to evaluate whether the biological activity exerted by ASA could be related to the steroid nucleus involved in their chemical structure, in this study, estrone was used as a pharmacological tool. The experimental data showed that ASA reduced infarct size, in a dose-dependent manner, compared with estrone; these data suggest that possibly the pyran ring or the functional groups bound to pyran ring of ASA could be responsible for its biological activity. This finding is supported by some reports which indicate that several pyran derivatives can exert an effect on the cardiovascular system [33 - 35] and can reduce the area infarction by inducing changes in left ventricular pressure [36, 37]. Analyzing these data, in this study, the effect exerted by ASA on left ventricular pressure was evaluated; the results showed that ASA decreases the left ventricular pressure in a dose-dependent manner compared with estrone and conditions control.

On the other hand, in the search for a molecular mechanism involved in biological activity induced by ASA on left ventricular pressure, earlier reports indicated that several compounds can induce changes in the left ventricular pressure through estrogen receptor activation [38,39]. To evaluate this hypothesis, in this study, the biological activity exerted by ASA on left ventricular pressure in the absence or presence of tamoxifen was evaluated. The results showed that ASA decreases left ventricular pressure and this effect was not inhibited by tamoxifen; this phenomenon indicated that molecular mechanism involved in the biological activity of ASA on left ventricular pressure was not via estrogenreceptor activation.

Since earlier reports indicated that some compounds can exert changes on left ventricular pressure through $\beta_{2}$ adrenergic receptor activation [40], in this study, the biological activity of ASA on left ventricular pressure was 
evaluated in the absence or presence of butoxamine ( $\beta_{2}$-adrenergic receptor inhibitor) [41]. The results showed that ASA decreased left ventricular pressure and this effect was not inhibited by butoxamine; this phenomenon indicated that molecular mechanism involved in the biological activity of ASA on left ventricular pressure was not via $\beta_{2}-$ adrenergic receptor activation.

On the other hand, other reports indicated that some substances can exert changes in the pressure of the left ventricle through $\mathrm{A}_{2}$-adenosine receptor and this phenomenon may result in a decrease in the infarct area [41, 42]. Therefore, in this study, the effect exerted by ASA on left ventricular pressure was determined, both in the absence or presence of ZM241385 ( $\mathrm{A}_{2}$-receptor adenosine antagonist) [43] The results showed that ASA decreases left ventricular pressure and this effect was inhibited by ZM241385. These data indicated that the effect exerted by ASA on left ventricular pressure was via $\mathrm{A}_{2}$-adenosine receptor activation.

On the other hand, it is important to mention that the interaction of some substances with $\mathrm{A}_{2}$-adenosine receptor could involve the synthesis and release of cAMP [44]. Therefore, in this study, an experimental alternative was carried out to evaluate the possibility that ASA could exert changes on cAMP levels; the results showed that ASA significantly increases the cAMP concentration compared with the conditions control.

\section{CONCLUSION}

The Amino-Steroid-Anthracenone derivative (ASA) is a particularly interesting compound because the biological activity exerted against ischemia-reperfusion injury involves a molecular mechanism different in comparison with other drugs; this phenomenon may constitute a novel therapy for ischemia-reperfusion injury translated as a decrease in the heart failure; however, it is important to carry out toxicity studies of this compound to rule out any adverse effect.

\section{ETHICS APPROVAL AND CONSENT TO PARTICIPATE}

All experimental procedures and protocols used in this investigation were reviewed and approved by the Animal care and use committee of Autonomous University of Campeche (Faculty of Chemical-Biological Sciences) with No. PI-420/12 and were in accordance with the Guide for the Care and Use of Laboratory Animals.

\section{HUMAN AND ANIMAL RIGHTS}

No humans were used in the experiments. All the reported experiments involving animals used in the study were in accordance with the Animal Ethics Committee of Autonomous University of Campeche (Faculty of ChemicalBiological Sciences) with No. PI-420/12.

\section{CONSENT FOR PUBLICATION}

Not applicable.

\section{CONFLICT OF INTEREST}

The authors declare no conflict of interest, financial or otherwise.

\section{ACKNOWLEDGEMENTS}

Declared none.

\section{REFERENCES}

[1] Yusuf S, Hawken S, Ounpuu S. Effect of potentially modifiable risk factors associated with myocardial infarction in 52 countries (the INTERHEART study): Case-control study. Lancet 2004; 364(9438): 937-52. [http://dx.doi.org/10.1016/S0140-6736(05)67663-5] [PMID: 16271645] 
[2] Thygesen K, Alpert JS, White HD. Universal definition of myocardial infarction. J Am Coll Cardiol 2007; 50(22): $2173-95$. [http://dx.doi.org/10.1016/j.jacc.2007.09.011] [PMID: 18036459]

[3] Pfeffer MA. Left ventricular remodeling after acute myocardial infarction. Annu Rev Med 1995; 46: 455-66. [http://dx.doi.org/10.1146/annurev.med.46.1.455] [PMID: 7598478]

[4] Kloner RA, Przyklenk K, Whittaker P. Deleterious effects of oxygen radicals in ischemia/reperfusion. Resolved and unresolved issues. Circulation 1989; 80(5): 1115-27.

[http://dx.doi.org/10.1161/01.CIR.80.5.1115] [PMID: 2553296]

[5] Figueroa-Valverde L, Díaz-Cedillo F, Rosas-Nexticapa M, García-Cervera E, Pool-Gómez E. Evaluation of activity exerted by a steroid derivative on injury by ischaemia/reperfusion. Afr J Pharm Pharmacol 2014; 8(5): 157-67. [http://dx.doi.org/10.5897/AJPP2013.3908]

[6] Gilewski W, Błażejewski J, Karasek D, et al. Are changes in heart rate, observed during dobutamine stress echocardiography, associated with a response to cardiac resynchronisation therapy in patients with severe heart failure? Results of a multicentre ViaCRT study. Kardiol Pol 2018; 76(3): 611-7.

[PMID: 29297189]

[7] Liggett SB, Mialet-Perez J, Thaneemit-Chen S, et al. A polymorphism within a conserved $\beta(1)$-adrenergic receptor motif alters cardiac function and $\beta$-blocker response in human heart failure. Proc Natl Acad Sci USA 2006; 103(30): 11288-93. [http://dx.doi.org/10.1073/pnas.0509937103] [PMID: 16844790]

[8] Domanski M, Norman J, Pitt B, Haigney M, Hanlon S, Peyster E. Diuretic use, progressive heart failure, and death in patients in the Studies of Left Ventricular Dysfunction (SOLVD). J Am Coll Cardiol 2003; 42(4): 705-8. [http://dx.doi.org/10.1016/S0735-1097(03)00765-4] [PMID: 12932605]

[9] Corvalán H, Casanegra P, Chamorro S, Jalil M, Valenzuela P. Comparación de los efectos clínicos y neurohumorales de milrinona y captopril en pacientes con insuficiencia cardíaca crónica. Bol Cardiol Chile 1988; 7(4): 289-300.

[10] Follath F, Cleland J, Just H, Papp J, Scholz H, Peuhkurinen K. Steering committee and investigators of the Levosimendan Infusion versus Dobutamine (LIDO) study. Efficacy and safety of intravenous levosimendan compared with dobutamine in severe low-output heart failure (the LIDO study): A randomized double-blind trial. Lancet 2002; 360(9328): 196-202. [http://dx.doi.org/10.1016/S0140-6736(02)09455-2] [PMID: 12133653]

[11] Bregagnollo E, Fortes A, Cicogna A. AvaliaÃßão dos efeitos inotrópicos e vasodilatadores do lactato de milrinona em pacientes com cardiomiopatia dilatada e insuficiência cardíaca grave. Arq Bras Cardiol 1999; 72(2): 149-54. [http://dx.doi.org/10.1590/S0066-782X1999000200003] [PMID: 10488574]

[12] Tischler M, Smith T. Digitalis: Its current place in the treatment of heart failure. Mod Concepts Cardiovasc Dis 1990; $59: 67-72$.

[13] Secknus MA, Marwick TH. Evolution of dobutamine echocardiography protocols and indications: Safety and side effects in 3,011 studies over 5 years. J Am Coll Cardiol 1997; 29(6): 1234-40. [http://dx.doi.org/10.1016/S0735-1097(97)00039-9] [PMID: 9137218]

[14] Ahmed A, Rich MW, Fleg JL, et al. Effects of digoxin on morbidity and mortality in diastolic heart failure: The ancillary digitalis investigation group trial. Circulation 2006; 114(5): 397-403.

[http://dx.doi.org/10.1161/CIRCULATIONAHA.106.628347] [PMID: 16864724]

[15] Gol V, Barroso P. Farmacología de la insuficiencia cardíaca. Farm Hosp 1996; 20: 149-56.

[16] Adams K, Patterson H, Gattis W. Relationship of serum digoxin concentration to mortality and morbidity in women in the digitalis investigation group trial: A retrospective analysis. J Am Coll Cardiol 2005; 46(3): 497-504.

[17] Yusuf S, Pitt B, Davis CE, Hood WB, Cohn JN. Effect of enalapril on survival in patients with reduced left ventricular ejection fractions and congestive heart failure. N Engl J Med 1991; 325(5): 293-302. [http://dx.doi.org/10.1056/NEJM199108013250501] [PMID: 2057034]

[18] Pitt B, Zannad F, Remme WJ, et al. The effect of spironolactone on morbidity and mortality in patients with severe heart failure. Randomized Aldactone Evaluation Study Investigators. N Engl J Med 1999; 341(10): 709-17. [http://dx.doi.org/10.1056/NEJM199909023411001] [PMID: 10471456]

[19] Tang H, Zhu Y, Teumelsan N, et al. Discovery of MK-7145, an oral small molecule ROMK inhibitor for the treatment of hypertension and heart failure. ACS Med Chem Lett 2016; 7(7): 697-701. [http://dx.doi.org/10.1021/acsmedchemlett.6b00122] [PMID: 27437080]

[20] Voets M, Antes I, Scherer C, et al. Heteroaryl-substituted naphthalenes and structurally modified derivatives: Selective inhibitors of CYP11B2 for the treatment of congestive heart failure and myocardial fibrosis. J Med Chem 2005; 48(21): $6632-42$. [http://dx.doi.org/10.1021/jm0503704] [PMID: 16220979]

[21] Voets M, Antes I, Scherer C, et al. Synthesis and evaluation of heteroaryl-substituted dihydronaphthalenes and indenes: Potent and selective inhibitors of aldosterone synthase (CYP11B2) for the treatment of congestive heart failure and myocardial fibrosis. J Med Chem 2006; 49(7): 2222-31. [http://dx.doi.org/10.1021/jm060055x] [PMID: 16570918]

[22] Follmann M, Ackerstaff J, Redlich G, et al. Discovery of the soluble guanylate cyclase stimulator vericiguat (BAY 1021189) for the treatment of chronic heart failure. J Med Chem 2017; 60(12): 5146-61. 
[http://dx.doi.org/10.1021/acs.jmedchem.7b00449] [PMID: 28557445]

[23] Okawa T, Aramaki Y, Yamamoto M, et al. Design, synthesis, and evaluation of the highly selective and potent G-protein-coupled receptor kinase 2 (GRK2) inhibitor for the potential treatment of heart failure. J Med Chem 2017; 60(16): 6942-90. [http://dx.doi.org/10.1021/acs.jmedchem.7b00443] [PMID: 28699740]

[24] Sarabia-Alcocer B, Figueroa-Valverde L, Díaz-Cedillo F, Hau-Heredia L, Rosas-Nexticapa M. García-Cervera. Activity induced by a naphthalene-prazosin derivative on ischemia/reperfusion injury in rats. Pharmacol Pharm 2014; 5: 1130-42. [http://dx.doi.org/10.4236/pp.2014.512123]

[25] Figueroa-Valverde L, Rosas-Nexticapa M, Mateu-Armand V, et al. Design and synthesis of pyranacyclodecaphen-3,6diyliden)bis(azanylidene))bis(ethan-1-amine) derivative with positive inotropic activity. Bioint Res Appl Chem 2018; 8(3): 3161-9.

[26] Bayne K. Revised Guide for the Care and Use of LaboratoryAnimals Available. Physiologist 1996; 9: 208-11.

[27] Valverde LF, Cedillo FD, Ramos ML, Cervera EG, Quijano K, Cordoba J. Changes induced by estradiol-ethylenediamine derivative on perfusion pressure and coronary resistance in isolated rat heart: L-type calcium channel. Biomed Pap Med Fac Univ Palacky Olomouc Czech Repub 2011; 155(1): 27-32.

[http://dx.doi.org/10.5507/bp.2011.018] [PMID: 21475374]

[28] Blatt RJ, Clark AN, Courtney J, Tully C, Tucker AL. Automated quantitative analysis of angiogenesis in the rat aorta model using Image-Pro Plus 4.1. Comput Methods Programs Biomed 2004; 75(1): 75-9. [http://dx.doi.org/10.1016/j.cmpb.2003.11.001] [PMID: 15158050]

[29] Hocht C, Opezzo L, Gorzalczany S. Una AproximaciónCinética y Dinámica de Metildopa en Ratas conCoartación Aórtica Mediante Microdiálisis. Rev Argent Cardiol 1999; 67: 769-73.

[30] Kersten JR, Montgomery MW, Pagel PS, Warltier DC. Levosimendan, a new positive inotropic drug, decreases myocardial infarct size via activation of K(ATP) channels. Anesth Analg 2000; 90(1): 5-11. [http://dx.doi.org/10.1097/00000539-200001000-00003] [PMID: 10624967]

[31] Node K, Kitakaze M, Kosaka H, Minamino T, Funaya H, Hori M. Amelioration of ischemia- and reperfusion-induced myocardial injury by 17ß-estradiol: Role of nitric oxide and calcium-activated potassium channels. Circulation 1997; 96(6): 1953-63. [http://dx.doi.org/10.1161/01.CIR.96.6.1953] [PMID: 9323086]

[32] Lauro FV, Francisco DC, Elodia GC, et al. Evaluation of activity of an estrogen-derivative as cardioprotector drug using an ischemiareperfusion injury model. Int J Clin Exp Med 2015; 8(8): 12041-55. [PMID: 26550116]

[33] Ashwood VA, Cassidy F, Evans JM, Gagliardi S, Stemp G. Synthesis and antihypertensive activity of pyran oxygen and amide nitrogen replacement analogues of the potassium channel activator cromakalim. J Med Chem 1991; 34(11): 3261-7. [http://dx.doi.org/10.1021/jm00115a015] [PMID: 1659637]

[34] Atwal KS, Grover GJ, Ferrara FN, et al. Cardioselective antiischemic ATP-sensitive potassium channel openers. 2. Structure-activity studies on benzopyranylcyanoguanidines: Modification of the benzopyran ring. J Med Chem 1995; 38(11): 1966-73. [http://dx.doi.org/10.1021/jm00011a016] [PMID: 7783128]

[35] Auchampach JA, Maruyama M, Cavero I, Gross GJ. The new K+ channel opener Aprikalim (RP 52891) reduces experimental infarct size in dogs in the absence of hemodynamic changes. J Pharmacol Exp Ther 1991; 259(3): 961-7. [PMID: 1762089]

[36] Lee B, Seo H, Yoo S, Kim S, Lim H, Shin H. Differential action of KR 31378, a novel potassium channel activator, on cardioprotective and hemodynamic effects. Drug Dev Res 2001; 54(4): 182-90. [http://dx.doi.org/10.1002/ddr.10028]

[37] Lee BH, Seo HW, Yoo SE. Cardioprotective effects of (2S,3R,4S)-N'-benzyl-N"-cyano-N-(3,4-dihydro-2-dimethoxymethyl-3-hydroxy-2methyl-6-nitro-2H-benzopyran-4-yl)-guanidine (KR-31372) in rats and dogs. Pharmacology 2004; 70(2): $74-82$. [http://dx.doi.org/10.1159/000074671] [PMID: 14685010]

[38] Skavdahl M, Steenbergen C, Clark J, et al. Estrogen receptor-beta mediates male-female differences in the development of pressure overload hypertrophy. Am J Physiol Heart Circ Physiol 2005; 288(2): H469-76. [http://dx.doi.org/10.1152/ajpheart.00723.2004] [PMID: 15374829]

[39] Donaldson C, Eder S, Baker C, et al. Estrogen attenuates left ventricular and cardiomyocyte hypertrophy by an estrogen receptor-dependent pathway that increases calcineurin degradation. Circ Res 2009; 104(2): 265-75. [http://dx.doi.org/10.1161/CIRCRESAHA.108.190397] [PMID: 19074476]

[40] Levy B. The adrenergic blocking activity of N-tert.-butylmethoxamine (butoxamine). J Pharmacol Exp Ther 1966; $151(3)$ : $413-22$. [PMID: 4380047]

[41] Akatsuka Y, Egashira K, Katsuda Y, et al. ATP sensitive potassium channels are involved in adenosine A2 receptor mediated coronary vasodilatation in the dog. Cardiovasc Res 1994; 28(6): 906-11. [http://dx.doi.org/10.1093/cvr/28.6.906] [PMID: 7923297]

[42] Jordan JE, Zhao ZQ, Sato H, Taft S, Vinten-Johansen J. Adenosine A2 receptor activation attenuates reperfusion injury by inhibiting neutrophil accumulation, superoxide generation and coronary endothelial adherence. J Pharmacol Exp Ther 1997; 280(1): 301-9.

[PMID: 8996210] 
[43] Keddie JR, Poucher SM, Shaw GR, Brooks R, Collis MG. In vivo characterisation of ZM 241385, a selective adenosine A2A receptor antagonist. Eur J Pharmacol 1996; 301(1-3): 107-13.

[http://dx.doi.org/10.1016/0014-2999(96)00020-9] [PMID: 8773453]

[44] Smits GJ, McVey M, Cox BF, Perrone MH, Clark KL. Cardioprotective effects of the novel adenosine A1/A2 receptor agonist AMP 579 in a porcine model of myocardial infarction. J Pharmacol Exp Ther 1998; 286(2): 611-8.

[PMID: 9694911]

\section{(C) 2018 Lauro et al.}

This is an open access article distributed under the terms of the Creative Commons Attribution 4.0 International Public License (CC-BY 4.0), a copy of which is available at: (https://creativecommons.org/licenses/by/4.0/legalcode). This license permits unrestricted use, distribution, and reproduction in any medium, provided the original author and source are credited. 